\title{
Rice Growth Stages Mapping with Normalized Difference Vegetation Index (NDVI) Algorithm Using Sentinel-2 Time Series Satellite Imagery
}

\author{
Bangun Muljo Sukojo ${ }^{\mathrm{a},{ }^{*}, \text { Rizki Hari Kurniawan }}{ }^{\mathrm{a}}$ \\ ${ }^{a}$ Department of Geomatics Engineering, Institut Teknologi Sepuluh Nopember, Surabaya, 60111, Indonesia \\ Corresponding author: "bangunms@gmail.com
}

\begin{abstract}
Rice as one of the staple food commodities consumed by most of Indonesia's population. In terms of the rice consumption level, the trend always follows national population growth every year. In 2016, Bojonegoro Regency reached 1,050,000 tons of rice; hence, it obtained a surplus of $\mathbf{7 5 0 , 0 0 0}$ tons of rice from the production target. Considering this potency, it is necessary to monitor the stability of agricultural production regularly. This study monitored the rice growth stages by utilizing remote sensing data of Sentinel2 optical satellite imagery. Analyzing the growth stages of rice plants can be done through the vegetation index algorithm. The algorithm used in this study is the Normalized Difference Vegetation Index (NDVI) in time series. From the analysis of NDVI time-series graphs, the correlation between NDVI values of Sentinel-2 images and the rice growth stages is 0.896 with a coefficient of determination of 0.803 or $80.34 \%$. The seedling phase has an NDVI value $<0.224$. The vegetative phase has a range of values of NDVI $0.224-0.894$. The generative phase has NDVI value range of $0.894-0.270$. The fallow phase has a range of NDVI values $<0.270$. The results of the Sentinel2 image classification obtained classification accuracy-test values for images on January 9, 2019 with a Kappa coefficient of 0.7824 and overall accuracy of $83.87 \%$.
\end{abstract}

Keywords - NDVI; rice growth stages; sentinel-2; time series.

\section{INTRODUCTION}

Rice is one of the staple food commodities that is consumed by the majority of Indonesia's population [1]. In terms of the rice consumption level, the trend always follows population growth every year. In 2017 , rice consumption in Indonesia was $114.6 \mathrm{~kg}$ per capita per year. In connection with increased consumption, it is necessary to increase the production. Bojonegoro Regency as a mainstay rice producer in East Java Province, has a vision of realizing the dream of becoming a national food barn. In 2016, rice productivity in Bojonegoro Regency reached 1,050,000 tons of rice, hence it obtained a surplus of 750,000 tons of rice from the production target. According to data from the National Statistics Agency, rice production in Bojonegoro Regency in 2017 reached 5.40 tons/Ha. Considering this potential, it is necessary to have a method to monitor the stability of agricultural production regularly. One method of monitoring rice or other annual crops that can be done is to use remote sensing satellite data. Utilization of remote sensing can explain more detailed information to see a land cover, including paddy fields where each land has a different growth phase. Conducting the analysis of rice plants' growth phase can be done using the vegetation index algorithm. The algorithm used in this study is the Normalized Difference Vegetation Index (NDVI). NDVI is a vegetation greenness index determined from the photosynthetic activity of vegetation [2]. NDVI has a better correlation coefficient with spectral data in the field (field spectrometer) compared to other vegetation index algorithms, such as EVI (Enhanced Vegetation Index) [3].

Furthermore, EVI was developed as an alternative vegetation index to overcome some of the limitations of NDVI [4]. Growth model of symmetrical bell-shaped rice plants [5]. Rice plants have 4 growth stages, including seedling, vegetative, generative, and fallow phases [6]. To be able to distinguish between the vegetative and generative phases, at least two different satellite images are needed at the date of acquisition ( $t$ and $t-1$ ). Extracting time-series NDVI values will bring up the rice growth stages pattern, which is visualized on the NDVI time-series graph. This study aims to identify the rice planting phase in Bojonegoro Regency so that 
the rice growth phase pattern and its classification are known. This study's results are expected to be used to determine the time of harvest in each rice field plot or used to estimate rice productivity in Bojonegoro Regency in subsequent studies.

\section{MATERIAL AND METHOD}

\section{A. Tools and Data}

The data used in this research were 4 scenes of Sentinel-2 data (T49MEM, T49MEN, T49MFM, and T49MFN) with the acquisition date of December 2018 to May 2019. All data were processed using SNAP and related software.

\section{B. Research Method}

This research was conducted in Bojonegoro Regency, East Java Province. Geographically, Bojonegoro Regency is in the position of $6^{\circ} 59^{\prime}-7^{\circ} 37^{\prime}$ South and $112^{\circ} 9^{\prime}$ - $112^{\circ} 25^{\prime}$ East. Kabupaten Bojonegoro Regency has an area of 230.706 Ha.

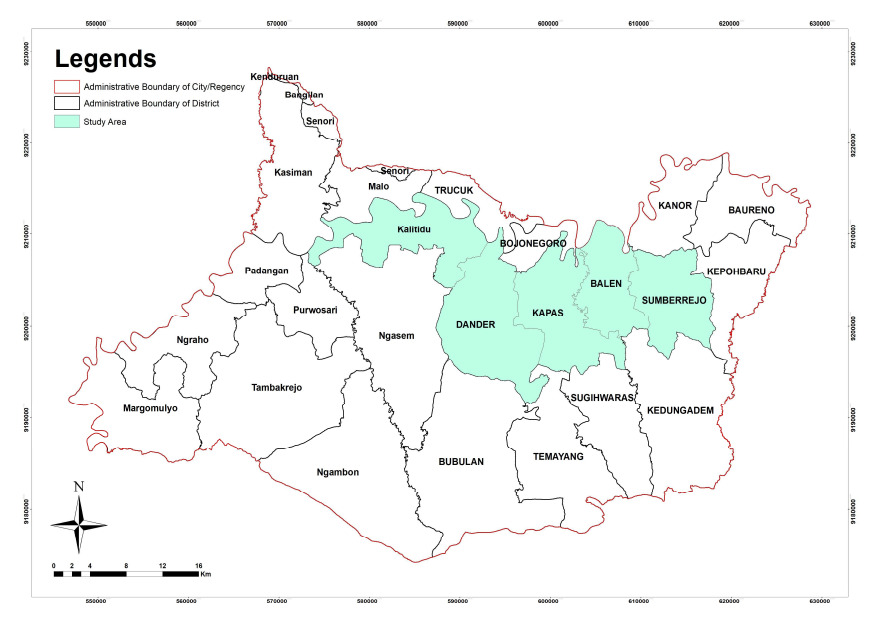

Fig. 1 Research Location Map

At the first processing step, raw data of Sentinel-2 was corrected from atmospheric effect using Sen2Cor. This tool is a processor in SNAP software for converting Sentinel-2 product level 1C (Top-of-Atmosphere Reflectance) to Level 2A (Bottom-of-Atmosphere Reflectance), performing atmospheric correction, and cirrus correction. The output product format is equivalent to level $1 \mathrm{C}$ product with three different spatial resolutions of 10, 20, and $60 \mathrm{~m} \mathrm{[7].}$

Determining the rice growth stages can be performed using vegetation index algorithm. This research using Normalized Difference Vegetation Index (NDVI) algorithm to analyze the rice growth stages in Bojonegoro Regency. NDVI is a standard method for comparing the level of greenness of vegetation in satellite imagery data. NDVI calculation aims to determine the phase of rice planting in the processed satellite imagery and the range of NDVI values in each phase. The NDVI vegetation index value ranges from -1 to 1 . The formula of NDVI is shown below.

$$
N D V I=\frac{N I R-R E D}{N I R+R E D}
$$

The rice growth stages can be determined by analyzing the dynamics or pattern of time series NDVI from Sentinel-2 imagery. Rice has several phases during the growth period. The four stages of rice growth are Seedling, Vegetative, Generative, and Fallow [8].
NDVI values is collected in several samples for all acquisition date to perform the time series NDVI chart. This research also performed ground checking activity to ensure the correlation level between satellite data and real data. Groundchecking activities aim to get the sample points' coordinates, determine the rice growth stages in the sample points, and get the spectral value (NDVI) in the field. Measurements were performed using an IR camera mounted on a drone. The result of processing photos from IR cameras is vegetation index (NDVI) photos in the data collection field. Retrieval of coordinates is done with the help of a handheld GPS. Rice growth stages at the sample point are obtained by conducting interviews with local farmers regarding rice age at the sample point.

NDVI obtained from the ground checking activity and NDVI from the satellite image then performed a regression analysis to determine the relationship between the two data. The magnitude of the effect of NDVI images on NDVI in the field is interpreted from the values of $\mathrm{R}^{2}$ (coefficient of determination) and $\mathrm{R}$ (correlation coefficient) [9]. Furthermore, the rice planting phase classification is carried out on satellite images using the Supervised Classification method according to the rice growth stages' results.

\section{RESULTS AND DISCUSSION}

\section{A. NDVI Result}

In this study, the vegetation index used is the Normalized Difference Vegetation Index (NDVI). NDVI value calculations are performed on all satellite image acquisition dates. The NDVI vegetation index value ranges from -1 to 1 [10]. The NDVI calculation aims to estimate the rice growth stages from a multitemporal NDVI value graph (time series). The statistical value of NDVI calculation results for Sentinel2 Level 2A images is shown in Table 1.

TABLE I

NDVI RESULT ON SENTINEL-2 LEVEL 2A

\begin{tabular}{cc}
\hline Variabels & S2A L2A Januari 09, 2019 \\
\hline Total Pixels & 120560400 \\
Minimum & -0.996 \\
Maximum & 0.999 \\
\hline
\end{tabular}

From Table 1, NDVI satellite images have a range of close enough values to the standard. This indicates a very high level of greenness variation in vegetation. The higher the value of NDVI (close to 1), the higher the level of greenery, applies vice versa.

\section{B. Groundchecking Result}

Sampling was carried out on January 25-26, 2020 in 5 (five) districts in Bojonegoro Regency, including the Districts of Kalitidu, Dander, Kapas, Balen, and Sumberrrejo. Rice samples are rice fields that have an area of more than $10 \times 10$ meters. This is because the spatial resolution of the Sentinel2 satellite imagery for the red, green, blue, and NIR channels is 10 meters.

The sampling aims to determine rice growth stages when the ground checking was carried out and determine the NDVI value of the field by using an IR camera and a drone. The photo acquisition was carried out 8 (eight) times in 5 (five) 
Districts in Bojonegoro Regency. The NDVI IR camera results and the distribution of sample points can be seen in Table 2. The NDVI statistics from IR cameras can be seen in table 2 below.

TABLE II

NDVI VALUES FROM IR CAMERA

\begin{tabular}{ccccc}
\hline \multirow{2}{*}{ No. } & Flight Number & \multicolumn{3}{l}{ NDVI } \\
\cline { 3 - 5 } & & Minimum & Maximum & Mean \\
\hline 1 & Flight 1 & -1.000 & 1.000 & 0.044 \\
2 & Flight 2 & -1.000 & 0.973 & 0.236 \\
3 & Flight 3 & -1.000 & 0.839 & 0.307 \\
4 & Flight 4 & -1.000 & 1.000 & 0.035 \\
5 & Flight 5 & -1.000 & 0.757 & 0.456 \\
6 & Flight 6 & -1.000 & 1.000 & 0.143 \\
7 & Flight 7 & -1.000 & 0.771 & 0.262 \\
8 & Flight 8 & -1.000 & 0.554 & 0.254 \\
\hline
\end{tabular}

From the results of ground checking, most rice growth stages are in the seedling and vegetative phases. This is because January is the beginning of subround 1 , which is the planting phase. Some experience the ripening phase, namely the generative and fallow phases. In Balen and Kalitidu Districts, several sample points experienced a generative phase, while in Kapas District, 4 (four) sample points experienced fallow phases.

\section{Sentinel-2 NDVI and IR Camera NDVI Correlation Test}

The correlation between Sentinel-2 NDVI and IR Camera NDVI obtained in the field is expressed by the regression line equation. The coefficient of determination or $\mathrm{R}^{2}$ is one of the simple measures and is often used to test a regression line equation's quality. The regression graph between Sentinel-2 NDVI on January 9, 2019 with the IR Camera NDVI shown in Figure 2 below.

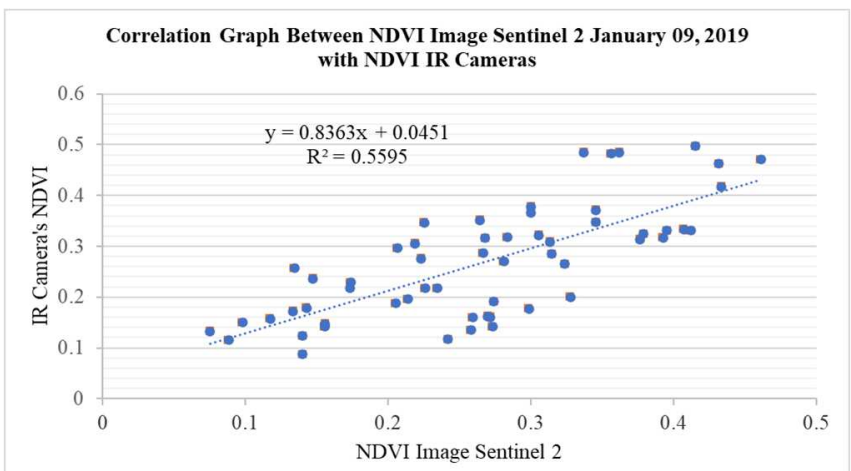

Fig. 2 Correlation Graph Between Sentinel-2 NDVI on January 09, 2019 with NDVI from IR Camera

The coefficient of determination $\left(\mathrm{R}^{2}\right)$ obtained from two data relationships is 0.560 with a correlation coefficient $(\mathrm{R})$ of 0.748 .

\section{Analyzing Rice Growth Stages}

NDVI values determine the age of rice. At the beginning of the growing season, the NDVI value is minimal and categorized as seedling body density or non-vegetation [11]. As it grows, its value will increase to the maximum when rice is in the generative phase. During the generative phase, the maximum NDVI value is due to the maximum amount of chlorophyll in leaf mesophyll tissue as shown in Figure 3.

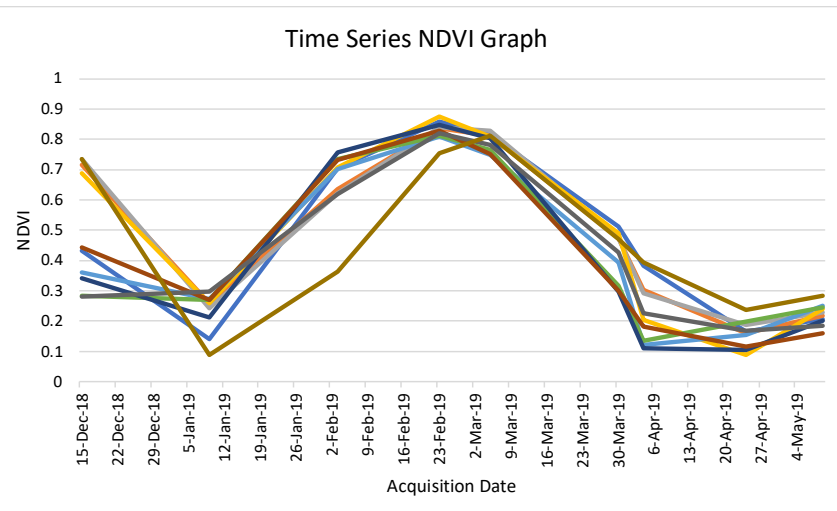

Fig. 3 Time Series NDVI Graph

The rice planting phase starts from the seedling phase in January 2019, where NDVI has a minimum value. This is because most rice fields are water with low chlorophyll content and low vegetation density in the seedling phase. In this seedling phase, the age of rice ranges from $0-3$ weeks after planting. Along with its growth, there was a significant increase in NDVI graph. This indicates that rice is entering the vegetative phase. The vegetative phase is characterized by an increase in chlorophyll and rice density along with rice growth. The beginning of the vegetative phase occurred on February 3, 2019 until reaching its peak on February 23, 2019. Rice is entering the generative phase marked by the start of graining until the maturing process. In this phase, the chlorophyll content begins to decrease, causing the NDVI graph to decrease. The beginning of the generative phase occurs at the end of February 2019 until March 30, 2019. In this phase the soil conditions are not as wet as the seedling and vegetative phases causing NDVI values are still higher than the seedling phase. Rice starts entering the maturing process until the rice leaves turn yellow in the fallow phase. This phase is marked by the maturity of rice that is ready to harvest to the post-harvest land condition that has not been replanted. In this phase, the NDVI value is at the minimum level which is almost the same as the NDVI value during the seedling phase.

From the NDVI time-series graph above, a correlation is made between the NDVI value and the rice planting phase to determine the correlation level of the rice planting phase's estimation through the NDVI time-series graph with the NDVI values in each phase. This research obtained the value of the coefficient of determination $\left(\mathrm{R}^{2}\right)$ is 0.803 , and the correlation coefficient is 0.896 , which means the NDVI value of the Sentinel-2 image, and the rice growth stages has a strong correlation for the above model. 


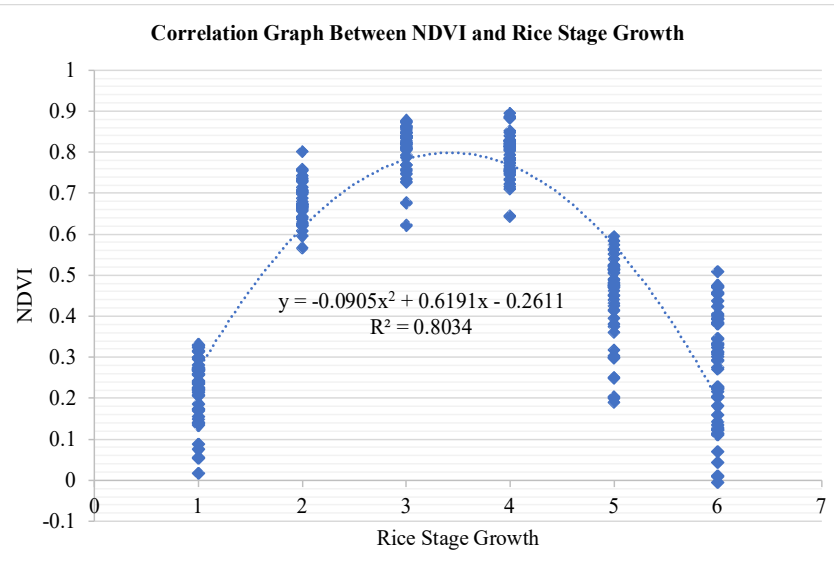

Fig. 4 Correlation Graph Between NDVI and Rice Growth Stages

To find out the range of NDVI values in each phase, the NDVI values are grouped in each phase according to Figure 4 above.

TABLE III

NDVI VALUES ON RiCE GROWTH STAGES

\begin{tabular}{ccc}
\hline No & Rice Growth Stages & NDVI \\
\hline 1 & Seedling & $<0.224$ \\
$2-3$ & Vegetative & $0.224-0.894$ \\
$4-5$ & Generative & $0.894-0.270$ \\
6 & Fallow & $<0.270$ \\
\hline
\end{tabular}

The type of rice used in several sample locations is INPARI. INPARI stands for Inbred Rice Irrigated Rice, is inbred rice planted on paddy fields. Inbred means the variety developed from one plant through self-pollination so that it has a high level of purity or homozygosity. Inpari has a planting age of 104-131 days after planting [12].

\section{E. Rice Growth Stages Classification}

The classification process is carried out in a guided manner by making training samples of at least five classes for each rice planting phase. The supervised classification method used is the Maximum Likelihood Classification method.

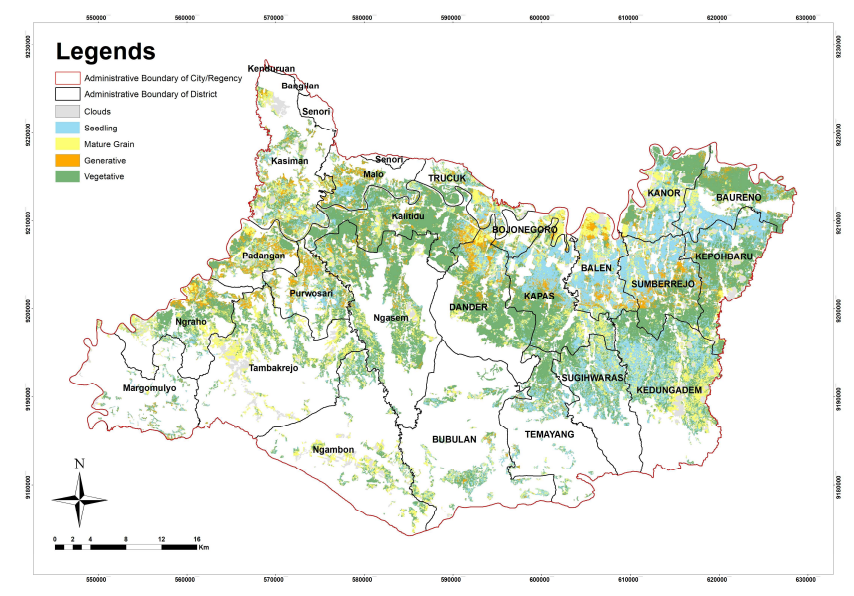

(a)

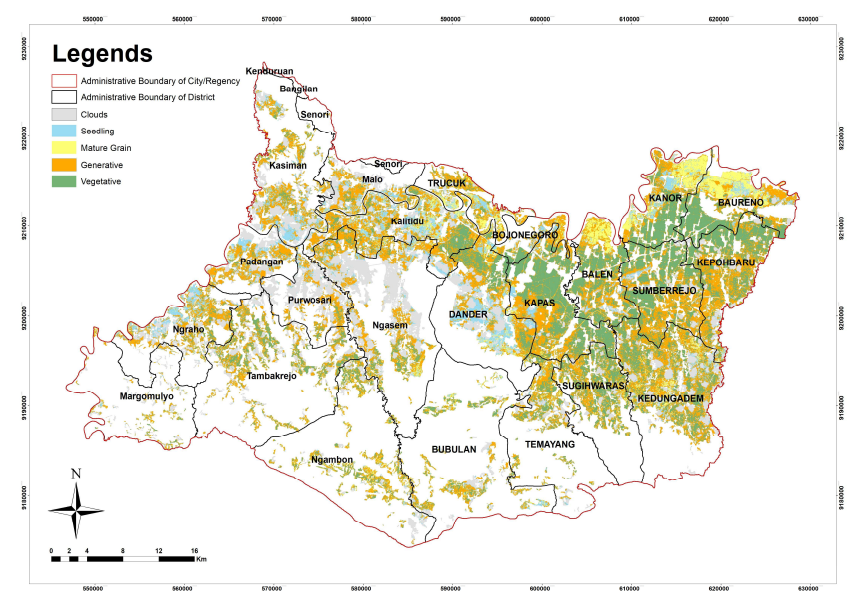

(b)

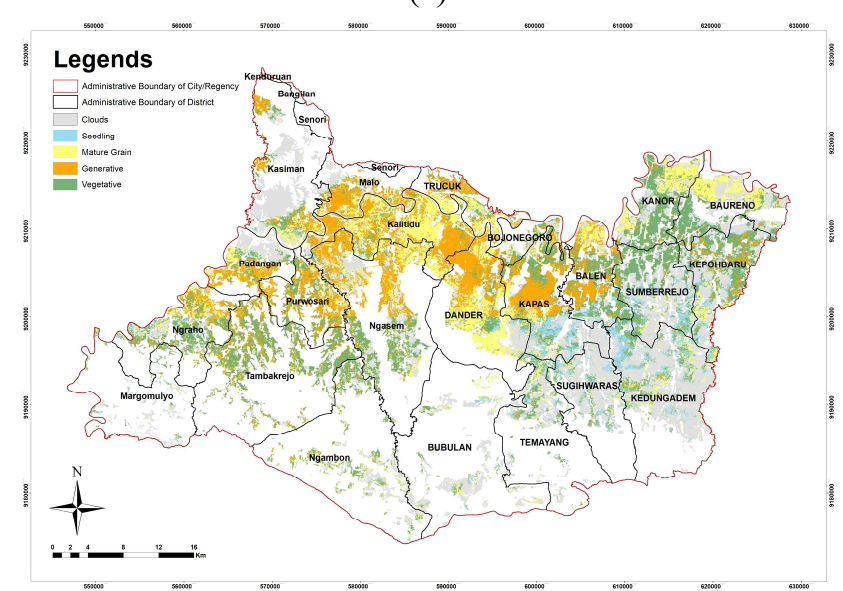

(c)

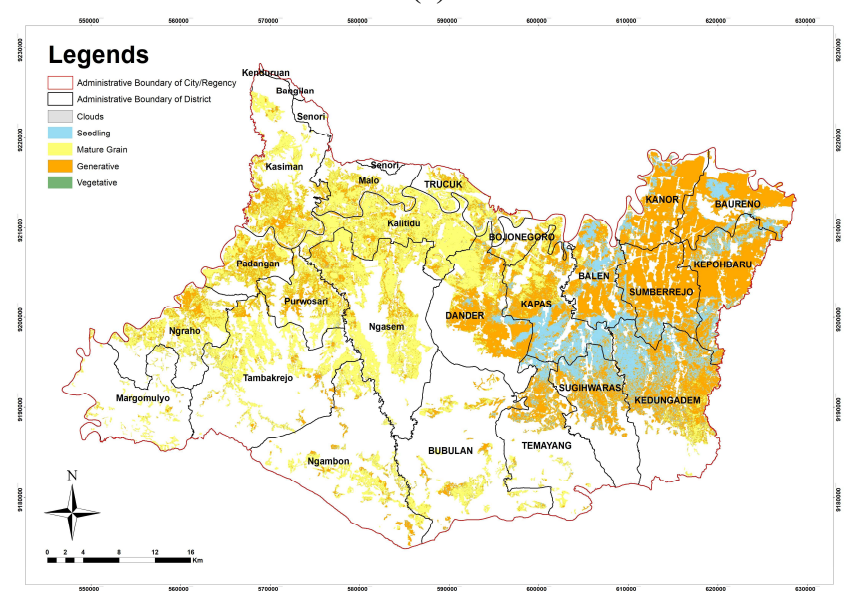

Fig. 5 Rice Growth Stages Classification Map on (a) January 09, 2019; (b) February 23, 2019; (c) March 05, 2019; (d) March 30, 2019

The classification result in Figure 5 (a) shows that most paddy fields are in the seedling and vegetative phases. The area of vegetative phase on the image dated January 9, 2019 is 42073,727 ha. The classification result in Figure 5 (b) shows that the paddy fields previously in the seedling and vegetative phases change to the vegetative and generative phases. In this case, the seedling phase in January 2019 changes to the vegetative phase in February, precisely on February 23, 2019 according to the image date. 
According to the image date, the vegetative phase in January changes to a generative phase in February 2019. The vegetative phase has an area of 26637,347 ha. The classification result in Figure 5 (c) shows that the paddy fields on March 5, 2019 were in the vegetative, generative, and fallow phases. Most of the paddy fields are still experiencing the vegetative phase. The area of the generative phase is 20754,812 ha. The classification result in Figure 5 (d) shows that on March 30, 2019, paddy fields in Bojonegoro Regency began at harvest time. As of this date, paddy fields are in 3 phases: seedling, generative, and fallow phases. The area of fallow phase is 38438,981 ha.

\section{CONCLUSION}

From the analysis of NDVI time-series graphs, the correlation between NDVI values of Sentinel-2 images and the rice planting phase is 0.896 with a coefficient of determination of 0.803 or $80.34 \%$. It obtained a range of NDVI values of the rice planting phase from Sentinel-2 images. The seedling phase has an NDVI value $<0.224$. The vegetative phase has a range of values of NDVI $0.224-0.877$. The generative phase has NDVI value range of $0.877-0.270$. The fallow phase has a range of NDVI values $<0.270$. The correlation value of NDVI Sentinel-2 images on January 9, 2019 with the NDVI IR Camera is 0.748 with a coefficient of determination $\left(\mathrm{R}^{2}\right)$ of 0.560 or $56 \%$. The classification results on January 9, 2019 showed that most of the paddy fields were in the seedling and vegetative phases with the area of each phase totaling 27708,946 ha and 42073,727 ha. According to the image date, the seedling phase in January 2019 changes to the vegetative phase in February, precisely on February 23, 2019. Simultaneously, the vegetative phase in January turned into a generative phase, with the area of each phase totaling 26637,347 ha and 38503,829 ha. On March 30, 2019, paddy fields in Bojonegoro Regency began in the harvest period. The area of fallow phase is 38438,981 ha, the generative phase area is $49157,631 \mathrm{ha}$, and the area of the seedling phase is 16246,521 ha.

To accomplish better result for this research, image date filtering with cloud cover is required at least $<30 \%$ or using radar data with an adjusted processing method. Making training samples for each class during the classification process must be done carefully, at least 25 pixels for each sample area, so there is no misinterpretation in the classification. Besides, to get better results, a comparison of NDVI with other vegetation indices is needed, such as EVI and MSAVI.

\section{REFERENCES}

[1] Ariani, M. 2004. The Dynamics of Household Rice Consumption and Its Relation to Diversification of Food Consumption in Indonesia. Agricultural Research and Development Agency, Ministry of Agriculture.

[2] Faizal, A., dan Amran, A.M. 2005. Model Transformasi Indeks Vegetasi Yang Efektif Untuk Prediksi Kerapatan Mangrove Rhizophora Mucronata. Institut Teknologi Sepuluh Nopember: Surabaya.

[3] Hafizh, A.S., Cahyono, A. B., and Wibowo, A. 2013. Use of NDVI and EVI Algorithms in Multispectral Imagery for Rice Growth Analysts (Case Study: Indramayu Regency, West Java). Department of Geomatics Engineering, Faculty of Civil, Planning, and GeoEngineering. Institut Teknologi Sepuluh November: Surabaya.

[4] Maksum, Z.U. 2015. Vegetation Index Classification. https:/geomusa.com/2015/10/enhanced-vegetation-index-evi/. Accessed on December 23, 2019.

[5] Dirgahayu, D. 2005. "The rice plant growth model uses MODIS data to estimate the age of lowland rice." Proceedings of MAPIN XIV's Annual Scientific Meeting; Surabaya Septermber 14-15, 2005. Surabaya.

[6] Noer, M. 2008. Estimation of Paddy Rice Production in Bekasi, Karawang and Subang Regencies. Department of Geography, Faculty of Mathematics and Natural Sciences, Universitas Indonesia: Depok.

[7] Main-Knorn, M., Pflug, B., Debaecker, V., dan Louis, J. 2015 "Calibration and Validation Plan for the L2A Processor and Products of the Sentinel-2 Mission”. $36^{\text {th }}$ International Symposium on Remote Sensing of Environment. Berlin: International Archives of the Photogrammetry, Remote Sensing and Spatial Information Sciences. 1249-1255.

[8] Research Center for Rice Plants. 2020. INPARI. http://bbpadi.litbang.pertanian.go.id/index.php/varietas-padi/inbridapadi-sawah-inpari. Accessed on May 20, 2020.

[9] Sugiarti, H. dan Megawarni A. 2010. Coefficient of Determination as a Measure of Model Compliance in Robust Regression. Center for Research and Community Service at the Open University.

[10] Danoedoro, P. 1996. Digital Image Processing Theory and Its Applications in the Field of Remote Sensing. Yogyakarta: Faculty of Geography, Universitas Gajah Mada.

[11] Indonesian Center for Agricultural Land Resources. 2006. Estimation of Productivity of Paddy Rice Through Satellite Image Analysis, 15, 853-869.

[12] Research Center for Rice Plants. 2020. INPARI. http://bbpadi.litbang.pertanian.go.id/index.php/varietas-padi/inbridapadi-sawah-inpari. Accessed on May 20, 2020. 